\title{
Introduction: Finding God in the Fieldnotes
}

\author{
Kyle B. T. Lambelet \\ Assistant Professor in the Practice of Theology and Ethics, Candler \\ School of Theology, Emory University, Atlanta, USA \\ kyle.lambelet@emory.edu \\ Jon Kara Shields \\ Instructor, Religion Department, Simpson College, Indianola, Iowa, USA \\ jonkara.shields@simpson.edu
}

Where is God? What locations should we turn to in order to identify God's activity in the world? What methods would be appropriate to attend to the presence (or absence) of God? And then, once we identify God's presence, what should we do in response? This special issue of Ecclesial Practices, compiled by the Fieldwork in Ethics interest group of the Society of Christian Ethics, highlights a dual post-liberal and liberationist inheritance, before arguing in the essays that follow, that Christian ethicists emerging from both orientations are unable to evade normative questions by turning to qualitative research. However, such an evasion was never true to our task. Instead, immersing ourselves in normative lifeworlds marked by brokenness and grace prompts us engage the grounds for ethical judgement anew: to reflect on God's presence, the presence of God's absence, and the persistent hope of liberation.

Over the past fifteen years, field work has become an established method for such attention in Christian ethics. Book series such as the T\&T Clark Studies in Social Ethics, Ethnography and Theology; distilling volumes like Anna Vigen and Christian Scharen's Ethnography as Christian Theology and Ethics; and this journal Ecclesial Practice all testify to the new emergence of ethnography as an accepted method of Christian ethics. ${ }^{1}$ Ethicists no longer argue about whether ethnographic methods of participant observation,

1 Christian Batalden Scharen and Aana Marie Vigen, Ethnography as Christian Theology and Ethics (London: Continuum, 2011). 
interviews, and other methods of qualitative analysis belong. Fieldwork has come of age in the guild.

Although sharing common ground in the use of ethnographic methods, the theological impetus for projects utilising fieldwork remain diverse. At the risk of too simple a typology, many projects in Christian ethics that draw on ethnographic materials gather under the banner of either post-liberal or liberation theologies. ${ }^{2}$ Let's take each in turn.

Post-liberals, who affirm that the church is the primary locus of God's action in the world, have looked to ecclesial practices as sites of normative revelation. Theologically, post-liberals affirm that the church, qua church, offers a distinctive grammar and discipline. Scripture is the font and the Spirit is the guide of this counter-cultural praxis. Christian ethicists in this tradition seek to identify the dispositions, discourses, or narratives that enable Christian recognition of a good life in the midst of a sinful world. Ethnography presents a way to attend to this distinctiveness (and divergences within it) through its own cultural logic. By entering the language game and ritual of a community, the ethnographer can witness to biblical forms of ecclesial life. Through interviews, jottings, fieldnotes, and memos, the ethnographer textualises the community's life, and reads it in relation to scripture and tradition. For example, Paul Fiddes takes up such an intratextual approach in his elaboration of the story of the Trinity as event by reflection on linkages with the stories of church members. ${ }^{3}$ The audience and remit of such post-liberal work is the Christian community bounded by shared institutional forms. Christopher Craig Brittain's discussion of interfaith partnership recognises a parish's sense of the sufficiency of collaborating with the neighbouring Muslim community for their own reasons without attempting inter-traditional dialogue to discover a unified or coherent overlap in their notion of the good. ${ }^{4}$ Similarly, work on Fresh Expressions, missional, or emerging churches has grasped at the thin stretching of ecclesial grace into the world, whilst keeping the focus on God's presence in and with the (sometimes messy) church as a contained system. ${ }^{5}$

2 Ted Smith proposes this typology in his essay "Troeltschian Questions for "Ethnography as Christian Theology and Ethics,"' Practical Matters 6 (2013), http://practicalmattersjournal. org/issue/6/centerpieces/troeltschian-questions-for-ethnography-as-christian-theology-andethics.

3 Paul S. Fiddes, 'God and Story in the Church and in Doctrine,' Ecclesial Practices 2, no. 1 (2015). pp. 5-22, 10.1163/22144471-00201001.

4 Christopher Craig Brittain, 'Partnership Not Dialogue: Lent and Ramadan under the Same Roof,' Ecclesial Practices 3, no. 2 (2016), pp. 190-209, 10.1163/22144471-00302005.

5 Clare Watkins and Bridget Shepherd, 'The Challenge of 'Fresh Expressions' to Ecclesiology,' Ecclesial Practices 1, no. 1 (2014), 92-110, https://doi.org/10.1163/22144471-00101005; Nigel 
While tending to focus on best practices, or practices which in the mind of the theologian reveal the character or activity of God against the world as a field of view, post-liberal work can be critical. For example, Peter Ward's book Celebrity Worship brings his previous scholarship on how people negotiate their identities in and through celebrity brand and culture to an examination of evangelical subculture and even church-as-celebrity. ${ }^{6}$ Here Ward recognises the failure of the church to maintain a distinctive grammar. The discipline of attention in its mediums threatens the church's message because the construction and representation of the self has become the ultimate concern. The work of scholars like Joyce Mercer and Mary McClintock Fulkerson similarly fits immanently sourced criticism into the broader work of building up redeeming, formative communities rooted in the idioms and practices of biblical faith. Engaging the wounds the church inflicts on itself Mercer and McClintock Fulkerson attend to how these wounds result from avoiding ongoing discernment of the churches' internal logics and thereby failing to produce practices that stand up to the scrutiny of the counter-cultural values that churches claim to cultivate. ${ }^{7}$ Following Nicholas Healy, ethnographers influenced by post-liberal theology may downplay the extent to which empirical study of churches can make visible the distinctiveness that springs from God's call to be church, claiming to do little more than identify the church as the world's Christian expression(s). ${ }^{8}$ And the work of scholars like Luke Bretherton deposes the prevailing ecclesiocentrism of post-liberal approaches by looking to interfaith practices of community organising as sites for democratic innovation. ${ }^{9}$ Nevertheless, the influence of post-liberal theology remains visible in the emphasis on the church as research site, in the empirical focus on the language and practice of God's people, and in a normative call to refine those practices as witnesses to a broken world.

Rooms, 'Understanding Local Churches as Porous Living Systems: Insights from the Tavistock Tradition,' Ecclesial Practices 6, no. 2 (2019), pp. 182-97, 10.1163/22144471-0o6o2005.

6 Pete Ward, Celebrity Worship (New York: Routledge, 2020).

7 Mary McClintock Fulkerson, Places of Redemption: Theology for a Worldly Church (Oxford: Oxford University Press, 2007); Joyce Ann Mercer, 'Conflicting Identities: An Ethnographic Account of Conflict and Schism in an Episcopal Parish,' Ecclesial Practices 3, no. 2 (2016), pp. 210-30, 10.1163/22144471-00302006.

8 Nicholas Healy, 'Ecclesiology, Ethnography, and God: An Interplay of Reality Descriptions,' in Perspectives on Ecclesiology and Ethnography, ed. Pete Ward, Studies in Ecclesiology and Ethnography (Grand Rapids, Mich: W.B. Eerdmans Pub. Co, 2012), pp. 182-99.

9 Luke Bretherton, Resurrecting Democracy: Faith, Citizenship, and the Politics of a Common Life, Cambridge Studies in Social Theory, Religion and Politics (New York: Cambridge University Press, 2015). 
Liberationists, who affirm God's preferential option for the poor, have looked to movements for justice in which the marginalised act as subjects for paradigms of ethical and political praxis. While the church, particularly Base Ecclesial Communities, represent an important locus of divine action for liberationists, more fundamental is God's preferential identification with the poor. We should attend especially to the poor because God has chosen to incarnate God's-self in their lives. For example, Ada María Isasi-Diaz's Mujerista Theology represents an early adoption of interview and participant observation methods for the development of liberationist praxis. ${ }^{10}$ Many scholars, such as Melissa Snarr and Edward Flores, have followed Isasi-Diaz's in specifying the turn to the margins through ethnographic modes of attention. ${ }^{11}$ Ethnography provides a method for attending to these lives, for joining in the work of solidarity, making method a work of discipleship. Christian Scharen, for example, has pointed to the connection between method and discipleship in his work on interviewing for social justice. ${ }^{12}$

For liberationists, it is the margins that provide the critical subject position from which to critique regnant ideologies and practices. Liberationists suspect that the focus on counter-cultural forms of life within Christian institutions is too easily co-opted into a preferential option for the church as institution or idea-broker. Like Eileen Campbell-Reed's research with Southern Baptist and Roman Catholic women and Jennifer Reed-Bouley's work on Black Catholic experiences, liberationist ethnography turns to marginalised people inside and outside ecclesial power structures for living judgements, refashioned practice, and reframed doctrine. ${ }^{13}$ Especially where it opens itself to lay piety practices and syncretism, liberation theology is postmodern in thinking of cultures and Christianities as hybrid, with interactive boundaries. Kyle Lambelet's

10 Ada María Isasi-Díaz, Mujerista Theology: A Theology for the Twenty-First Century (Maryknoll, NY: Orbis Books, 1996).

11 C. Melissa Snarr, All You That Labor: Religion and Ethics in the Living Wage Movement (New York: New York University Press, 2011); Edward Flores, Jesus Saved an Ex-Con': Political Activism and Redemption after Incarceration (New York: New York University Press, 2018).

12 Scharen writes, 'the spiritual practice of bending to those who are bent low by the world, becomes in hearing their voice of hope and resilience, a testimony and thanksgiving for what God already is in relation to the world.' Christian A.B. Scharen, 'Interviewing Interpreted as a Spiritual Exercise and Social Protest,' Ecclesial Practices 4, no. 2 (2017), pp. 218-36, 10.1163/22144471-00402004.

13 Jennifer Reed-Bouley, “'I Belong! And I'm Here to Stay!” U.s. Black Catholics' Faith and Faithfulness,' Ecclesial Practices 2, no. 2 (2015), pp. 177-97, 10.1163/22144471-00202006; Eileen R. Campbell-Reed, 'Living Testaments: How Catholic and Baptist Women in Ministry Both Judge and Renew the Church,' Ecclesial Practices 4, no. 2 (2017), pp. 167-98, 10.1163/2214447100402002. 6 . 
¡Presente! displays a method that crosses legal, cultural, and disciplinary boundaries as it tracks the transnational protests of a nonviolent social movement. ${ }^{14}$ Nevertheless, liberation theology refuses postmodern deconstruction or hybridity as an end in itself. Instead, it turns to the people constrained under oppressive social powers (some of them 'Christian') as witnesses to a God already present and enacting liberative Christian praxes of solidarity ${ }^{15}$

While this account of these strands-post-liberal and liberationist-is limited in its descriptive scope, it offers a quick way to organise the diverse projects of Christian ethicists who use ethnographic methods. Beyond methodological overlap, both strands agree that ethnographic methods provide a mode of attending to God's action in history, variously construed. Yet, laying bear this overlap raises fundamental theological questions.

Whether post-liberal or liberationist, these projects gather under a cultural turn that aims to evade the problem of normativity after Lessing's ditch. To be sure, the turn to culture is not one turn, but rather a constellation of strategies aimed at circumventing the problem Lessing identified: moving between the accidents of history to the truths of reason. ${ }^{16}$ These strategies affirm that there is no view from nowhere, that human knowing is determined by culture and power, and that ethicists are cultural producers. ${ }^{17}$ Given these insights, then, ethicists have looked toward material culture as a place to begin building up normative accounts. Rather than starting with abstract principles and specifying down to particular cases, these accounts start with the accidents of history and build up (more or less) toward truths of reason. But, the relationship between accident and truth remains fraught. Anthropologists have ensured the scientific validity of their discipline by suspending normative questions, reaffirming the gap between description and norm. For the anthropologist, it matters not whether God is actually present, what matters is whether people believe God is present and act on that belief. For the Christian ethicist, however, truthful speech about God's presence matters. Christian ethicists have

14 Kyle B. T. Lambelet, ;Presente! Nonviolent Politics and the Resurrection of the Dead (Washington DC: Georgetown University Press, 2019).

15 Here, liberationists may be said to reflect a Treoletschian distinction between the practice of the churches or other Christian institutions and the practice of Christianity as a way of life. See Ulrich Schmiedel, 'Praxis or Talk about Praxis? The Concept of Praxis in Ecclesiology,' Ecclesial Practices 3, no. 1 (2016), pp. 120-36, 10.1163/22144471-00301007.

16 Ted A. Smith, 'Redeeming Critique: Resignations to the Cultural Turn in Christian Theology and Ethics,' Journal of the Society of Christian Ethics 24, no. 2 (2004), pp. 89-113.

17 Sheila Greeve Davaney, 'Theology and the Turn to Cultural Analysis,' in Converging on Culture: Theologians in Dialogue with Cultural Analysis and Criticism, ed. Delwin Brown, Sheila Greeve Davaney, and Kathryn Tanner, (Oxford: Oxford University Press, 2001), pp. $3^{-16}$. 
something at stake in degrading the gap that Lessing identified. Yet, neither type that we have identified, post-liberal or liberationist, has successfully evaded this fundamental problem. After attending to the way that the articles in this issue draw on the strands we have articulated, we will return to the question of how ethnographic work in Christian ethics addresses the persistent gap between fact and norm, description and prescription, fallible human utterance and divine Word.

The papers in this issue, each in distinct ways, exemplify these liberationist and post-liberal strands, even as they pluralise and move beyond them. ${ }^{18}$ Where is God? These essays affirm that the gift of the incarnation reveals God in the messy materiality of human life. Turning not only to the poor and the church as privileged sites to attend to God's action in the world, this second generation of Christian ethicists taking up ethnographic methods turn to survivors of domestic violence, social service professionals, the earth, liturgical activists resisting gentrification, and even the wicked as sites where the ethnographer witnesses to God's activity. Moreover, the process of research itself creates moments of ethical reflection. By reflexively interrogating their own positionalities, these essays display modes of moral subjectivity and formation. Anthropology as a discipline and practice suggests that there is no person or social process that is not interesting. As projects in Christian ethics, these essays extend anthropology's disposition of curiosity with the affirmation that all the earth 'and the fullness thereof' testify to the activity of God. In so doing, each essay attends, in its own way, to God's presence (and absence) in the fullness of creation.

Ashley Theuring's essay most obviously develops the liberationist paradigm, consciously drawing on an inheritance from liberation theologians Ignacio Ellacuría, Jon Sobrino, and Ada María Isasi-Díaz. She finds manifestations of grace in circumstances of trauma and isolation by tacking between her interviews with domestic abuse survivors and resurrection narratives of scripture. In so doing, she illustrates a compelling case for Catholic theologians to utilise an abductive approach to theological enquiry. Building on existing commitments to a sacramental worldview and the preferential option for the poor, Theuring both invites and displays the power of adopting more frequent use of qualitative research methods.

By contrast, Ryan Juskus' essay shows a Barthian influence in its consideration of how theologians are witnesses to witness. Juskus articulates the relationships between theological ethnographer, Christian creation care movement

18 These papers were collectively prepared and workshopped for the 2020 meeting of the Society of Christian Ethics Fieldwork in Ethics interest group. 
researcher, and creation itself in the shared task of revealing God's love for all that God has made. Attending to the practices of a Christian creation care movement motivated by the human costs of bad ecological practices, the language of 'creation' already suggests that the movement operates within a normatively-laden religious grammar. However, Juskus's description of Restoring Eden's restorative truth-telling reveals a model of research activism aimed at a wider public discourse. The activism Juskus finds challenges resource extraction through grassroots knowledge production: drawing on scientific evidential epistemologies in order to pursue normative aims of care for creation. This research activism prompts Juskus's methodological insight. Theological ethnographers, too, are knowledge producers. They hold together professing the presence of God in particular historical moments and the danger of foreclosing on practical reasoning by too definitively drawing the boundaries of God's presence. Juskus articulates a 'witness methodology' which risks provisionally finding God amongst the elk or mountaintops in order to direct the attention of readers, as co-deliberators and wisdom-seekers, to these extra-ecclesial sites of God's presence.

Also concerned with how ethnography produces knowledge, Emily Dubie's reflection on her fieldwork amongst social workers reframes the peril of gathering bad data by way of interviews due to the ever present threat of misrepresentations. Dubie engages the layers of self-presentation that prevent interviews from producing transparent accounts of objective happenings. Rather than understanding this as a problem, Dubie highlights the value of these layers as reports that demonstrate social workers' constructions of the good. Following the liberationist insight that method can be a form of discipleship, Dubie attends to her own presence as interviewer whose reception of each interviewee's self-presentation is part of the interviewee's own ongoing moral evaluation. There is an intersubjective good present in the interplay between interviewee and researcher which makes changing representation over the course of an interview compelling 'data' in its own right, as evidence of accompanied self-analysis.

Sara Williams's paper takes us further down the road of implicating the researcher in the moral quandaries of her informants. Examining the racial tensions in a group of Christians seeking to organise a public liturgy of the Way of the Cross, Williams attends to how the organisers experience a conflict of practical reasoning around liturgical intention, reception, and continuance. Her critical insight brings together post-liberal practices of reflexivity and immanent criticism - which rely on retrieving the initial aim of the Way of the Cross practice-and a liberationist methodology of attention to the margins - that awakens the ethnographer to her own practices of exclusion. Writing 
up ethnographic observation from a privileged perspective can prompt an invitation to engage in vulnerability: Christians' intellectual awareness of the different perspectives of marginalised people does not on its own transform our perception. Becoming aware of and publicising one's own engagement with moral questions in the midst of describing divergences in a community's normative perspectives involves risk. But it is through that risk that one can invite readers into a reflexive examination of the perspective and affections at work in themselves. Williams's essay constructs an anthropology of the good that she utilises as a tool of ethical self-becoming, and in turn shares with the reader as a technology of the self.

Todd Whitmore's essay continues the attention on the researcher's self-disclosure by turning to the genre of confession. Through his fieldwork as an addiction recovery coach, Whitmore comes to see his mentees as 'the least of these,' consecrated to be the body of Christ. Confession as a mode of self-writing allows Whitmore to struggle retrospectively with God's presence in seemingly hopeless situations. Confession, Whitmore argues, allows ethnographic work to reveal theological insights without reducing the communities and persons to illustrative examples, an error he finds in post-liberal theologian Stanley Hauerwas. Yet, Whitmore's attention to his mentee Sam requires a return to ecclesial practices in a way that draws us back to the post-liberal commitment to the distinctive grammars of Christianity. In his search for the dispositions and perseverance that will enable him to continue the research work as a part of his own recovery, Whitmore's confession includes taking up the practices of Eucharistic adoration and veneration of St. Jude and Our Lady of Sorrows.

We conclude the issue with an essay by Michael Grigoni who examines the post-liberal and liberationist presuppositions and methods animating Whitmore's Imitating Christ in Magwi. In this essay, Grigoni shows that Whitmore's project, while framed in liberationist commitments, draws upon a narrative derived from the post-liberal project. Whitmore's liberationist sensibilities draw him to focus on the Acholi people victims of war, poverty, and disease. Yet, his post-liberal intuitions lead him to reflect on the practices of imitation that add up to a life of discipleship. Through this engagement, Grigoni finds Whitmore writing a thick description of Christian discipleship at the margins. But even if, as Grigoni argues, these narratives complete 'post-liberal theology's unfinished task,' marking off a known territory as the location where God inhabits our world, they may not complete the project of theology (if we are to take Whitmore's contribution to this issue to heart).

Together, these papers helpfully break any reductive typology we might offer to distinguish between post-liberal and liberationist strands. They combine and push beyond initial attempts to attend to God's activity ethnographically 
in the church or in the poor. In doing so, they stake out an ambitious trajectory of research that pluralises and expands the scope of how we might theologically attend to the messy accidents of history.

As is now apparent, Theuring's essay is the only essay in the collection to 'study down,' collaborating from a position of privilege with research partners who experience multiple marginalisations within both the ecclesial and the larger civic community. The other four essays in this issue primarily engage laterally with research subjects and partners who are in positions of power relatively similar to the researchers' own. Nevertheless, an emphasis on practical reasoning about how Christians perform solidarity with others when they are not self-consciously acting as a part of the church community runs through the other essays. Juskus looks at how the testimony to harm and God's love as resistance to harm is a part of the practice of solidarity. Dubie attends to how research itself participates in processes of reflexivity around solidarity and paternalism - contributing to the formation of self-presentation and shared aspirations for liberative engagements within systems of constraint. Williams, similarly, reflects on how research processes can provide invitations for the ethnographer herself to experience self-becoming. This in turn makes her better able to engage in solidarity and draw the reader into moments of vulnerable self-examination. Finally, Whitmore offers a similar invitation to confession as a mode of engaging the theological disclosures that occur in reflecting back on periods of observation. Though making this invitation, he also maintains that the lives we live and observe together cannot be reduced to narrative soundbites that move us from one point of theo-logic to another.

The lives by which we express solidarity (including through the research process) and the lives which experience solidarity amount to much more than data for a theological argument. Put another way, God's actions in history constantly exceed our ability to witness to God's presence, in the language of Christian practice or any form of human meaning-making. We celebrate this abundance even as it reminds us that the sufficiency of any theology we create is provisional and dependent upon grace to speak words about the ineffable Word. We fall short due to our failures and our finitude. But just as the reality of the Word breaks in on our insufficient speech, so also we express our hope that God's presence precedes and transcends our modes of relationship-our ethical modes of engagement - in order to enable expressions of solidarity with those whom God loves. Together, these papers invite us to increase our curiosity about the presence of God in a broken world. Of course, anthropological curiosity has often been won at the price of ethical relativism. Only by suspending morals have anthropologists been able to enter as fully as possible into native ways of being and understanding. This relativism 
resonates for theologians who affirm God's presence in the fullness of creation. A doctrinal affirmation of God's presence does not do away with the God-forsakenness of the world as we find it.

What remains under-theorised in the larger turn to ethnography in Christian ethics is the practice of discernment, or, in ethical terms, practical reason. Ethicists too may be tempted to leave the resolution of is and ought unstated, suspecting that if we do ethnography well enough the practical reasoning of those we study will stand in for our own. But immersion into a normatively-construed life world does not stand in for an articulation of how God is present in that world how we come to judgement upon it. No one finds the unalloyed Spirit of God or confronts the unmistakable experience of Incarnation. As witnesses to God's presence (and absence) the ethnographer engages in an act of faith. How do we discern God's presence? How do we come to judgement about that presence? And what would our identification of that presence of absence indicate about how we ought to live? These questions remain. 